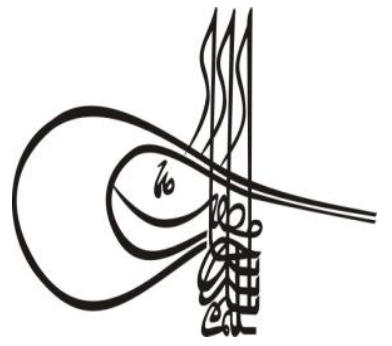

Received/Geliș: 08.09.2019

\section{Turkísh Studies Educational Sciences}

Volume 14 Issue 5, 2019, p. 2767-2785

DOI: 10.29228/TurkishStudies.38895

ISSN: 2667-5609

Skopje/MACEDONIA-Ankara/TURKEY

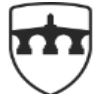

INTERNATIONAL BALKAN UNIVERSITY

EXCELLENCE FOR THE FUTUR IBU.EDU.MK

Research Article / Araştırma Makalesi

Article Info/Makale Bilgisi

SAccepted/Kabul: 15.10.2019

Gor Report Dates/Rapor Tarihleri: Referee 1 (10.10.2019)-Referee 2 (13.10.2019)

This article was checked by iThenticate.

\title{
ÖĞRETİM DURUMLARI MODELİ: KURAMSAL TEMELLERİ BAĞLAMINDA KAPSAMLI BİR DERLEME ÇALIŞMASI
}

\author{
Etem YEŞILYURT*
}

\begin{abstract}
Öz
Bireyin bilişsel, duyuşsal ve psiko-motor davranışlarını kendi yaşantısı yoluyla istendik yönde ve kalıcı izli olarak değişimini amaçlayan eğitim sistemlerinin iki temel ögesi bulunmaktadır. Bu ögeler, eğitimin öğrenenlerle ilgili olan ögesi "öğrenme" ve öğretenlerle ilgili olan ögesi "öğretim” kavramlarıyla karşılık bulmaktadır. Eğitimin genel ve uzak hedeflerine ulaşılması için kuramsal alt yapılarının geçerli ve güvenilir olduğu öğretim modellerine dayalı olması büyük önem taşımaktadır. Öğretim modeli, büyük olasıllkla ulaşılabilecek öğrenme hedeflerine hangi şartlar altında ulaşılacağını ve bu șartları en iyi sağlayacak yöntemlerin belirlenmesi olarak tanımlanabilir. Alanyazında yer alan ve eğitim sistemlerini etkileyen birçok öğretim modeli bulunmaktadır. Bu modellerden biri de Gagne tarafından geliştirilen "Öğretim Durumları Modelidir." Öğretim durumları modeli davranışçı, bilişsel ve bilgiyi işleme modellerinden yararlanmış ve bu modellerin en genel özelliklerini bir bakıma sentezlemiştir. Alanyazında yer alan çoğu kaynaklarda öğretim durumları modeli yer verilmediği; yer veren kaynaklarda modelin teorik temellerinin yüzeysel olarak ele alındığ görülmektedir. Öte yandan bu modelin etkililiğinin sınandığı veya modelle ilgili araştırmaların sayısı ülkemizde oldukça azdır. Öğretim durumları modeli temelde öğrenme aşamaları, öğrenme kategorileri (çeşitleri-türleri-hiyerarşisi) ve öğrenme ürünleri (çıktıları) olmak üzere üç ana bileşenden oluşmaktadır. Derleme niteliği taşıyan bu çalışma kapsamında ulaşılan kaynaklarda öğretim durumları modeliyle ilgili olan bilgiler derlenmiş, bir araya getirilmiş, teorik (kuramsal) temelleri ve temel bileşenleri (öğrenme aşamaları, öğrenme kategorileri ve öğrenme ürünleri) bir bütünlük içerisinde açıkça ve detaylı bir şekilde "öğretim durumları modeli öğretmen el kitabı" niteliğinde açıklanmıştır. Bu bakımdan çalışmanın hem alanyazına ve
\end{abstract}


hem de öğretim-öğrenme sürecinin temel ögesi olan öğretmenlere uygulamada katkı sağlayacağı umulmaktadır.

Anahtar Kelimeler: Gagne, Öğretim Durumları Modeli, Öğretim Modeli, Öğretim İlke ve Yöntemleri.

\title{
INSTRUCTIONAL EVENTS MODEL: A COMPREHENSIVE REVIEW IN THE CONTEXT OF THEORETICAL FOUNDATIONS
}

\begin{abstract}
There are two basic factors of education systems which aim to change the individual's cognitive, affective and psycho-motor behaviors through their own lives in the desired direction and permanently.These factors correspond to the concepts of "learning" which is related to the learner, and "teaching" which is related to the teacher. It is crucial that the theoretical backgrounds are based on teaching models in which they are valid and reliable in order to achieve the general and distant goals of education. The instructional model can be defined as identifying the conditions under which the learning objectives are likely to be achieved and the methods that best meet these requirements. There are many instructional models in the literature that affect education systems. One of these models is "Instructional Events Model" developed by Gagne. The instructional events model benefited from behavioral, cognitive, and information processing models and synthesized the most general characteristics of these models in a way. It is seen that the theoretical foundations of the model are discussed superficially.On the other hand, the number of studies on the effectiveness of this model or the researches about the model is quite low in our country. The instructional events model consists of three main components: learning stages, learning categories and learning products. In this study, which is a review, the information related to the instructional events model is compiled, gathered and the theoretical foundations and basic components are explained clearly and in detail as a instructional events model: teacher handbook. In this respect, it is hoped that the study will contribute both to the literature and to the teachers who are the basic elements of the teaching-learning process in practice.
\end{abstract}

\section{STRUCTURED ABSTRACT}

There are two basic factors of education systems which aim to change the individual's cognitive, affective and psychomotor behaviors through their own lives in the desired direction and permanently. These factors correspond to the concepts of "learning" which is related to the learner, and "teaching" which is related to the teacher.

It is crucial that the theoretical backgrounds are based on teaching models in which they are valid and reliable in order to achieve the general and distant goals of education. The instructional model can be defined as identifying the conditions under which the learning objectives are likely to be achieved and the methods that best meet these requirements. There are many instructional models in the literature that affect education

Turkish Studies - Educational Sciences

Volume 14 Issue 5, 2019 
systems. One of these models is "Instructional Events Model" developed by Gagne. This model has been used in instructional design of all disciplines and is generally accepted.

The instructional events model benefited from behavioral, cognitive, and information processing models and synthesized the most general characteristics of these models in a way. In this respect, the instructional events model which outlines the introduction, development and conclusion parts of a course is also a instructional model in accordance with the general principles of the teaching process. Even though the name is not known much in our country, it has been one of the most used instructional models used by teachers in the preparation of lesson plans, determination and follow-up of courses. However, Instructional Events Model is not used many sources directly related to the subject especially in textbooks of the faculty of education such as the teaching principles and methods special teaching methods, educational psychology, learning psychology, learning and teaching theories and It is seen that the theoretical foundations of the model are discussed superficially.

On the other hand, the number of studies on the effectiveness of this model or the researches about the model is quite low in our country. According to Gagne, learning occurs as a result of many successive processes. However, since some processes occur simultaneously or in parallel, the order of these internal processes may change. The internal processes of learning are influenced by external events involving stimuli in the environment. The task of the teacher; is to select, organize, arrange and supervise these external events in accordance with learning processes in line with learning objectives. External impact may not be necessary for internally motivated and self-directed learners. However, in schools, almost all students need to be supported with external activities in order to fully utilize their existing capacities.

The instructional events model consists of three main components: learning stages, learning categories and learning products. Gagne identified the stages of learning in an effective lesson and gradually explained what teaching activities should be given to provide these learning processes. The order of these teaching activities may vary. Sometimes the successive order of teaching activities may change, and one teaching activity can also perform the function of another.

Learning stages

$>$ Gain attention of the students

$>$ Inform students of the objectives

$>$ Stimulate recall of prior learning

$>$ Present the content

$>$ Provide learning guidance

$>$ Elicit performance (practice)

$>$ Provide feedback

$>$ Assess performance

$>$ Enhance retention and transfer to the job

Turkish Studies - Educational Sciences

Volume 14 Issue 5, 2019 
According to Gagne, learning is a process of eight interrelated categories. The sort and characteristics from most simple learning type to the most complex learning type are as follows:

Hierarchy of learning

$>$ Signal learning

$>$ Stimulus-response learning

$>$ Psychomotor connection learning

$>$ Verbal association learning

$>$ Multiple discrimination learning

$>$ Concept learning

$>$ Principle learning

$>$ Problem solving

Five types of learning products are handled according to the teaching status model. Learning products and their characteristics in this classification can be explained as follows:

Learning products (outcomes)

$>$ Verbal information

$>$ Intellectual skills

$>$ Cognitive strategy

$>$ Attitude

$>$ Motor skills

B. Bloom, a contemporary of Gagne, stated that people's learning capacities consist of three main areas: cognitive, affective and psychomotor. Although revised, this classification has continued to be acceptable until today. Gagne is the only teaching theorist who offers an integrated taxonomy of teaching outcomes (learning products) covering all three areas. As a matter of fact, verbal knowledge, intellectual (cognitive-cognitive) skills and cognitive strategies are cognitive domains; attitudes affective domain; motor skills represent the piso-motor domain or include behaviors (gains, objectives, etc.) in these domains

In this study, the information related to the instructional events model is compiled, gathered and the theoretical foundations and basic components are explained clearly and in detail as an instructional events model: teacher handbook. In this respect, it is hoped that the study will contribute both to the literature and to the teachers who are the basic elements of the teaching-learning process in practice.

Keywords: Gagne, Instructional Events Model, Instructional Model, Teaching Principles and Methods.

\section{Giriş}

Bireyin bilişsel, duyuşsal ve psiko-motor davranışlarını kendi yaşantısı yoluyla istendik yönde ve kalıcı izli olarak değişimini amaçlayan eğitim sistemlerinin iki temel ögesi bulunmaktadır. Bu ögeler, eğitimin öğrenenlerle ilgili olan ögesi "öğrenme" ve öğretenlerle ilgili olan ögesi olan "öğretim" kavramlarıyla karşılık bulmaktadır. Eğitimin genel ve uzak hedeflerine ulaşılması hem "öğrenme" hem de "öğretim" ögelerinin ve bu öge içerisinde yer alan alt öge veya bileşenlerin birbiriyle uyumlu, bu bağlamda eğitime yön veren kuramsal altyapılarının geçerli ve güvenilir olduğu öğretim ve öğrenme modellerine (kuramlarına) dayalı olması önem taşımaktadır. 
Sözcük olarak öğretim belli bir amaca göre gereken bilgileri verme işi, tedris, tedrisat, talim (TDK, 2019); kişinin belli bir amaca ulaşmasını sağlayacak bilgileri öğrenmesine yardım etme işi; öğrenmeyi kolaylaştıracak etkinlikleri düzenleme, araç-gereçleri hazırlama ve öğrenmede yol gösterme işi (Bakırcıoğlu, 2012) olarak tanımlanmaktadır. Akademik ve eğitimsel anlamda öğretim, insan yaşamının belli kesimlerinde kazandırılan, planlı, programlı, destekli, genellikle bir belge ile sonuçlanan; öğrenmenin gerçekleşmesi ve bireyde istenen davranışların gelişmesi için uygulanan süreçlerin tümü (Varış, 1996) şeklinde tanımlanmaktadır. Bunlar ve öğretimle ilgili alanyazında yer alan diğer tanımlar dikkate alındığında öğretim kavramının üç yönüne vurgu yapıldığı söylenebilir. Bu üç yönün birincisi belirli bir hedefe göre öğrencilere çeşitli bilgi ve becerileri öğretme; ikincisi bu bilgi ve becerileri bir alana veya konuya bağlı olarak gerçekleştirme; üçüncüsü ise öğrenmeyi kolaylaştıracak etkinlikleri düzenleme, araç-gereçleri temin etme ve rehberlik yapma olarak özetlenebilir (Güneş, 2014). Öğretimle ilgili yukarıda yer alan tanım ve açıklamalar dikkate alındığında öğretimin genellikle örgün eğitimin hedefleri (kazanımları) doğrultusunda, öğretmen eşliğinde, planlı, programlı, destekli ve kontrollü olarak okul, sınıf ve ders ortamlarında yapılan tüm etkinlikler olarak görüldüğü söylenebilir. Diğer bir deyişle öğretim; eğitimin okullara yansıyan veya kılavuzlanan, öğretim programlarının okul ve sınıf ortamında uygulanması halidir. Öğretimin uygulamada işlevsel olması onun bir modele dayalı olmasinı gerektirmektedir.

Öğretime yönelik felsefi bir bakış açısını yansıtan ve öğretimsel uygulamaların düzeyini ortaya koyan öğretim modeli (Taşpınar \& Atıcı, 2002); öğretim stratejilerini, yöntemlerini, tekniklerini seçme ve gerçekleştirmede etkili olan felsefi bir bakış açısı olarak tanımlanabilir (Taşpınar, 2012). Yakın anlamda olan başka bir tanımda göre öğretim modeli, büyük olasılıkla ulaşılabilecek öğrenme hedeflerine hangi şartlar altında ulaşılacağını ve bu şartları en iyi sağlayacak yöntemlerin belirlenmesi (Driscoll, 2005) olarak ifade edilmektedir. Dolayısıyla öğretim modelleri öğretmenlerin hangi koşullarda nasıl davranacağını, davranışların öğrenen üzerindeki etkisinin ne olacağını, farklı öğrenme koşulları için farklı öğretim yöntemlerini, değişkenlerin öğrencinin öğrenmesine nasıl etki etiğini, yeni bir bilginin ve öğrenme yaşantıların nasıl kazandırılacağını, bunun için öğretimin sıralamasının nasıl yapılması gerektiğini açıklamaya çalışmaktadır (Bruner, 1966; Landa, 1983; Reigeluth, 1989; Akt: Duman, 2007; Alkan, 2005; Fidan, 2012).

Öğretim modelleri bir öğretim programının temel ögeleri olan hedef, içerik, eğitim durumları (öğretim ve öğrenme süreci) ve sınama durumlarının (ölçme ve değerlendirme) tamamının şekillenmesine etki etmektedir. Öğretim modellerinin bu ögeler içerisinde özellikle öğretim ve öğrenme süreci üzerinde daha fazla etkiye sahip olduklarını söylemek mümkündür. Bir bakıma farklı öğretim modellerinin ortaya konması ögretim ve öğrenme sürecinin nasıl organize edilmesi gerektiğini, öğrencilerin daha iyi nasıl öğreneceklerini dikkate alarak ortaya konulmuşlardır. Bu modellerden biri de Gagne tarafından geliştirilen öğretim durumları modelidir. Öğretim durumları modeli alanyazında bazı kaynaklarda "öğretim modeli”, "öğretim etkinlikleri modeli", "Gagne'nin öğretim kuramı" gibi farklı isim veya başlıklar altında yer almaktadır. Bu çalışmada alanyazında yer alan çoğu kaynakta olduğu gibi ve daha fazla kabul gördüğü şekliyle "Öğretim Durumları Modeli” kavramı kullanılmış olup yukarıda yer alan farklı başlıkları ve içeriğini kapsamaktadır.

Konuyla doğrudan ilgili olan öğretim ilke ve yöntemleri, özel öğretim yöntemleri, eğitim psikolojisi, öğrenme psikolojisi, öğrenme ve öğretim kuramları gibi eğitim fakültesi ders kitapları başta olmak üzere alanyazında yer alan çoğu kaynakta öğretim durumları modeline yer verilmediği görülmektedir. Alanyazında az sayıda da olsa bazı kaynaklarda (Akpınar, 2012; Gökalp, 2014; Gündoğdu, 2016; Kaya, 2015; Senemoğlu, 2010) öğretim durumları modeline yer verilmiş ancak bu kaynakların tamamında ilgili model detaylı olarak ele alınmamıştır. Öte yandan bu modelin etkililiğinin sınandığı veya modelle ilgili araştırmaların sayısı ülkemizde oldukça azdır (Akçay, 2011; Baş, 2012; Donmuş Kaya, 2018; Gündüz, 2002; Gündüz, 2010; İlhan Beyaztaş, Kaptı \& Gelbal, 2013; Menzi, 2012; Özkök, 2010; Sünbül, Gündüz \& Y1lmaz, 2002; Tanyeri, 2004). Derleme niteliği taşıyan bu 
çalışma kapsamında öğretim durumları modelinin kuramsal temelleri detaylı bir şekilde ele alınmıştır. Modelle ilgili olan ancak farklı kaynaklarda yer alan bilgileri bir araya getirmesi bakımından bu çalışmanın alanyazına, öğretim ve öğrenme süreçlerine daha somut katkı sunacağı umulmaktadır.

\section{Öğretim Durumları Modeli}

Robert M. Gagne, tarihi İkinci Dünya Savaşı yıllarına kadar giden öğretim tasarımının öncülerinden birisi olarak bilinmektedir. Öğretim tasarımı modelini 1962'de ortaya koyan Gagne, 1965 'te ise beş öğrenme çıktısını ve bu çıktıları destekleyen dokuz aşamalı öğretim durumunu belirlemiştir (Lee, Owens \& Benson, 2002; Akt: Menzi, 2012; Yıldırım, 2015). Temeli Gagne tarafindan 1955 'te Askeri Psikolojisi'nin APA Bölümü'ne atıfta bulunularak atılan öğretim durumları modeline en fazla katkıyı daha sonraki yıllarda da yine içerisinde Gagne yer aldığı bilim insanları yapmıştır. Nitekim daha sonraki yıllarda Gagne ve Driscoll, (1988), Gagne, Briggs ve Wager (1992) ile Gagne ve Medsker (1996) tarafından yapılan çalışmalarda bu öğretim modeli daha da geliştirilmiştir (Driscoll, 2005).

Öğretim tasarımının cevabını aradığı temel soru olan “en iyi nasıl öğrenilir?” sorusuna hem davranışçı hem de bilişsel psikolojinin vereceği birçok cevap vardır. Öğretim durumları modeli, bu anlamda öğrenmeyle ilgili derin izler bırakmış olan bu iki yaklaşımın eksikliklerini tamamlayan bilişsel psikolojinin sorunlarını davranışçı yaklaşımla bütünleştiren ve her iki yaklaşımın sentezine dayalı bir model olarak öne çıkmaktadır (Baş, 2012; Eşgi \& Arslan, 2015). Gagne'nin, yaklaşık yirmi yılı aşkın zamanda geliştirme ve yenilenme yaptığı bu öğretim modeli davranışçı kökleriyle, öğrenme üzerine iyi öğretmenlerin sınıflarında ne yaptıklarının deneysel kanıtlarıyla bilişsel bilgi-işleme bakış açısını bir araya getirmektedir (Driscoll, 2005). Nitekim Gagne, öğrenmede içsel süreçlerin de etkili olduğunu belirtmekte ancak öğrenmenin gözlenebilir davranışlardan meydana geldiğini vurgulamaktadır. Öte yandan modelde yer alan öğretim aşamalarından sunulan bilgiyi önceki öğrenmelerle ilişkilendirme ve öğrenilen bilginin transfer edilmesi Gagne'nin modelinin yapılandırmacı öğrenme modeline doğru kaydığının bir göstergesi (Mergel, 1998; Akt: Menzi, 2012) olarak görülebilir. Ancak yapılandırmacı öğrenme modeli, öğretim durumları modelinden oldukça farklıdır. Çünkü yapılandırmacı öğrenme modeli tek bir kuram yerine, eğitim ve öğretimde geçerlilik kazanmış benzer yaklaşımların bir koleksiyonunu temsil etmektedir. Yapılandırmacı öğrenme modeli bilgiyi işleme modelinden çok Bruner, Vygotsky ve Piaget'in fikirleriyle daha uyumlu olan bir ögrenme modelidir (Driscoll, 2005). Öğretim durumları modeli davranışçı ve bilişsel öğrenme modellerinde olduğu gibi bilgiyi işleme modeline de uygun bir öğretim modelidir (Sönmez, 2007). Çünkü Gagne, bilgiyi işleme modelini kendi modeline bir temel olarak kabul etmektedir (Driscoll, 2005). Nitekim 1960'll yıllarda davranışçı akımının temsilcilerinden biri olan Gagne daha sonraki yıllarda bilgiyi işleme modelinin öncülerinden biri olmuştur. Bilgiyi işleme modelinin duyusal kayıt, kısa ve uzun süreli zihinsel yapıları (bellek türleri); dikkat, seçici algı, bilgiyi saklama (tutma), tekrar, gruplama gibi bilişsel süreçleri öğretim durumları modelinin dokuz aşamalı öğrenme süreçleriyle benzerlik göstermektedir. Öğretim durumları modeli esas itibarıyla öğretim sürecinde hedeflere ulaşmak için öğrenciye yol gösteren normatif bir yaklaşımdır (Donmuş Kaya, 2018). Gagne'nin öğretim durumları modeli, tüm disiplinlerin öğretim tasarımında kullanılmış genel kabul görmüş bir modeldir. Öğretim durumları modelinin özellikleri şöyle sıralanabilir (Akınoğlu, 2008; Karaağaçlı \& Erden, 2008):

$>$ Öğrenme, gözlenen davranışlardan anlaşı1ır ve farklı öğrenme türleri vardır.

> Farklı öğrenme ürünleri farklı öğretme-öğrenme stratejilerinin bir arada kullanılmasını gerektirir, öğrenmede farklı modeller bir arada uygulanabilir.

$>$ Dış ve iç faktörlerin etkisiyle oluşan öğrenme birbirine dayalı aşamalı ve birikimli bir süreçtir, bir örüntü içinde gerçekleşir.

$>$ Öğrenme, öğretmenin yaptıklarından çok öğrencilerin kendi yaptıkları ile olur, öğrenci kendi deneyimleri yoluyla yaparak, yaşayarak öğrenir.

$>$ Birikimli bir süreç olan öğrenmede zihinsel beceriler basitten karmaşığa doğru hiyerarşik bir yapı içerisinde oluşur. Yeni öğrenme, öğrenilmiş bilgi ve beceriler üzerinde inşa edilir. 
Öğrenme süreci sonunda varılacak hedeflerden başlanması öğretimin planlanmasını sağlamaktadır. Böylece öğrencilerin ilgili konuda nerede ve hangi aşamada oldukları bilindikten sonra öğretmen konuya nereden başlayacağını ve hangi öğrenme yaşantılarının kazandırılması gerektiğini daha kolay planlayabilir.

Öğretim durumları modeli temelde öğrenme aşamaları, öğrenme kategorileri (çeşitleri-türlerihiyerarşisi) ve öğrenme ürünleri (çıktıları) olmak üzere üç ana bileşenden oluşmaktadır. Tablo 1'de öğretim durumları modelinin bileşenlerine yer verilmiş ve bu bileşenler aşağıda detaylı bir şekilde açıklanmıştır.

Tablo 1: Öğretim Durumları Modelinin Bileşenleri

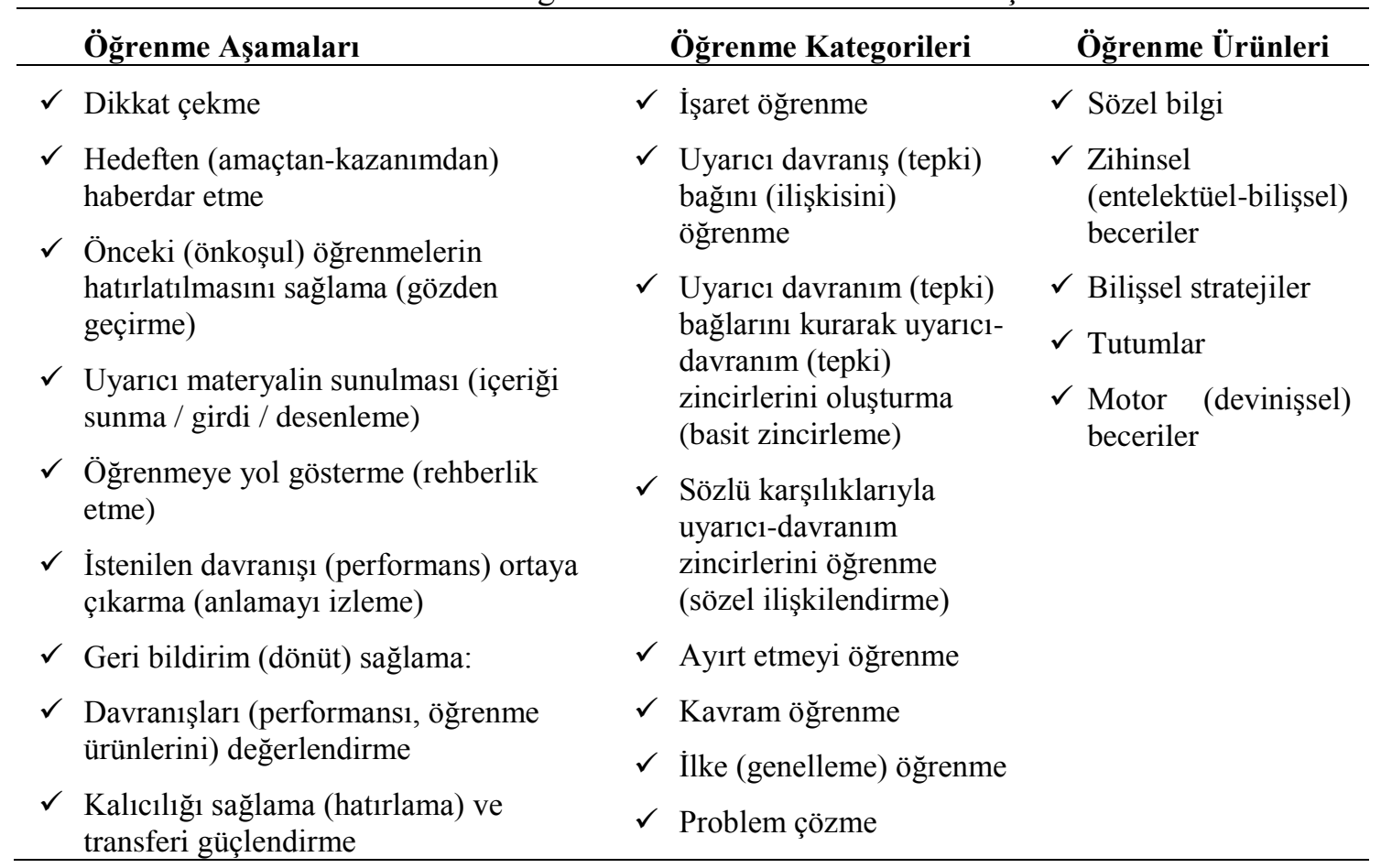

\section{A) Öğrenme Aşamaları}

Gagne, etkili bir derste yer alan öğrenme aşamalarını tespit etmiş ve bu aşamalarda yer alması gereken öğretim etkinliklerinin neler olması gerektiğini açıklamıştır. Gagne'ne göre öğretim etkinliklerinin ardışı sırası bazen değişebileceği gibi bir öğretim etkinliğini başka bir öğretim etkinliği de yerine getirebilir (Senemoğlu, 2010). Öğretim durumları modeline göre öğrenme aşamaları ve bu aşamaların genel özelliklerine aşağıda yer verilmiştir:

1. Dikkat çekme: Öğrenme sürecinin başlaması ve devam etmesi için gerekli bir önkoşul öğretim etkinliğidir. (Gagne \& Driscoll, 1988). Dikkat, zihin gücünün belli bir durumun ya da olayın açıklıkla kavranabilmesi için o durum ya da olay üzerinde yoğunlaşması olarak tanımlanabilir. $\mathrm{Bu}$ aşamada ilgi, ihtiyaç, bilişsel ve duyuşsal düzeylerine uygun yollarla öğrencilerin dikkati öğretim veya konuya çekilmelidir. Öğrencinin dikkatini çekmek için öğrenci düzeyine uygun olacak şekilde model, fikra, olgu, anı, olay, hikâye, soru sorma, şiir, şarkı, resim, şekil, espri, grafik vb. dikkat çekici unsurlara yer verilebilir (Taşdemir, 2003). Arzulanan öğrenmenin gerçekleşmesi öğrencilerin belli bir konuya dikkat ederek katılması ile mümkün olabilir. Dikkat ettiğimiz ya da dikkatimizi çeken uyarıcıları alarak gerekli tepkilerde bulunuruz. Dikkatimizi çeken özellikler ise ihtiyaçlarımıza uygunluk, önemlilik, 
güncellik, uyarıının şiddeti, uyarıcının veriliş şekli vb. gibi hususlardır. Öğrencinin dikkatini çekme, sözlü ya da sözsüz tekniklerle olabilir. Ses tonunu değiştirme, önemli bir noktaya tekrar etme ya da vurgulama, jest ve mimikler, dikkati çekilmek istenen öğrencinin gözlerine anlamlıca bakma, o öğrenciye doğru yürüme, parmaklarını o öğrenciye doğru uzatma, birkaç saniye hiçbir şey söylemeden sessizce bekleme vb. etkinlikler öğrencilerin dikkatini konuya çekebilir. Öğretmenin konunun öneminden bahsetmesi, konuyu öğrenmenin hangi sorunların çözümünde öğrenciye hangi katkıları sağlayacağını belirtilmesi de dikkat çekmenin farklı teknikleri arasında yer almaktadır (Özbek, 2011).

Merak, öğrencileri derse motive etmede ve dikkati çekmede önemli bir unsurdur. Öğrencileriniz neden bu konuyu bilmek istesin ya da neden dikkate almalıdır? sorusunun cevabı bu ögenin kârlığını oluşturmaktadır. Yaygın dikkat çekme yöntemlerinden biri genellikle soru sorularak, merak uyandırmaktır. Örneğin, enerji üzerine bir dersten "Beygir gücü kelimesinin nasıl oluş̧urduğumuzu hiç merak ettiniz mi, kim tahmin etmek ister?"; mitoloji üzerine bir dersin girişinden "Herhangi biriniz Yunan Tanrısı'nın adıyla anılan ünlü otomobil markasını hatırlayabilir mi?"; genel bilim ya da fizikteki bir dersten "Neden bazı bilim insanları, diğer gezegenlere seyahat etmenin uzay yolcularını gençleştireceğini düşünürler? Merak ve dikkat uyandırmada bir değer teknik ise belli bir çelişki ortaya koymaktır. Örneğin, "Yunan imparatorluğunun en güçlü zamanında neden çöktüğünü düşünüyorsunuz?" Gerçek yaşamdaki bir tutarsızlık da merak ve dikkat uyandırır. Örneğin, "Hayvanlar âlemindeki bazı küçük sınıflamalar neden insanlardan daha uzun yaşıyor?" Başlangıçta mantıksız gibi görünen bir şey de dikkati çeker. Örneğin, "Neden bir şey ileri gittiği zaman başka bir şey geriye gitmek zorundadır?" (Kılıç, Babacan \& Padem, 2014).

2. Hedeften (amaçtan-kazanımdan) haberdar etme: Amaç, yetiştirmek istediğimiz bireylerde bulunması uygun görülen ve eğitim yoluyla kazandırılabilir mahiyetteki özellikleridir. Öğrencilere, ders öncesinde ve dersin giriş aşamasında, ilgili dersin hangi hedefleri (kazanımları) kazandıracağı, dersin genel ve özel amaçlarının neler olduğu, ders bitiminde öğrencilerin kendilerinde hangi davranış değişikliği yaşamaları gerektiği açık ve net olarak izah edilmelidir. Öğrencinin kendinden beklenilenin ne olduğunu bilmesi öğrencinin başarısını olumlu yönde artırmakta öğrenme sürecine ilişkin kaygıları azaltmaktadır. Öğrenci ders öncesinde hedeften haberdar edildiğinde öğrenme ve öğretim sürecine ilişkin kaygıları azalır, sürece kendini hazırlar, harekete geçer, konu dışına çıkmaz, konu üzerinde yoğunlaşır ve öğretmene olan güveni artırır (Fidan, 2012).

Öğrencilerinizin ne bilmelerini ve ne yapabilmelerini istiyorsunuz? sorusu bu ögenin tam karşılığıdır. Öğrencilerin algılarını bir noktada toplamanın en etkili yolu, dersin sonunda ulaşmaları beklenen davranışsal çıktılardan onları haberdar etmektir. $\mathrm{Bu}$, dersin ya da ünitenin başında öğrencilerden yeterli olmaları için ne yapmaları beklendiğinden ya da öğrencilerin nasıl sınav olacaklarından bahsedilerek yapılabilir. Örneğin, "Sunulacak güç tanımlarının dördünü hatırlayın (fen dersi)" Bu ifadeler, öğrenenlerin ders bilgilerini nasıl hatırlayacakları ve kullanacakları konusunda seçici olmalarını ve ulaşmaları beklenen davranış düzeylerini bilmelerine olanak tanır. Enerji konusundaki dersin sonunda öğrencilerden gücün dört tanımını da hatırlamaları bekleneceği söylenirse o zaman sizin ders boyunca sunulan güç tanımları ya da kategorileri üzerine araştırmalarına, hatırlama ve zihinde tutma süreçlerine ağırlık vereceklerini bileceklerdir. Hedeflerden öğrenenleri haberdar etmek, öğrencilere zihinsel kancalar sağlayarak onların dersin öncesinde sahip oldukları düşüncelerini düzenlemelerine yardım eder. Bu durum, öğrenme süreçlerini etkin hale getirir ve öğrencilerin istenen davranış çıktılarını kazanmalarına ağırlık verir. Hedefleri bildirmenin en iyi yolu, öğrencilere ders sonunda gösterebilmeleri beklenilen örnek görevler sunmaktır. Bu durum, bir öğrenme çıktısı ile bağlantılı hareket fiilini bu davranışın testlerde, sınıf tartışmalarında ve soru-cevap oturumlarında değerlendirileceği bazı biçimlere dönüş̧ürür. Mesela, hayvanlar âleminin sinıflarıyla ilgili ünitenin başlangıcında, beklenen çıktılarla ilgili örnekler tahtaya yazılabilir (Kılıç, Babacan \& Padem, 2014). 
3. Önceki (önkoşul) öğrenmelerin hatırlatılmasını sağlama (gözden geçirme): Bir öğrenme konusunun (biriminin) öğrenilebilmesi için gerekli olan önceki öğrenmeye önkoşul öğrenme denir (Gagne \& Driscoll, 1988). Bu durumda yeni öğrenilecek bilgilerle ilgili olan daha önce öğrenilmiş bilgi ve becerilerin hatırlanması ve kullanılması öğrencinin öğrenme sürecine daha aktif katılmasını ve öğrenmeyi sürdürmesini sağlamaktadır (Fidan, 2012). Ön bilgilere sahip olma ve bu ön öğrenmelerin hatırlatılması öğrenci ile yeni öğrenilecek konu arasında bir köprü görevi görmektedir (Bloom, 1979). $\mathrm{Bu}$ nedenle öğretim sırasında önkoşul öğrenmelerin yani öğrencinin daha önce öğrendiği bilgi ve becerilerinin hatırlamasını sağlama anlamlı öğrenmenin gerçekleşmesi için gereklidir (Gagne, Briggs \& Wager, 1992). Bu durumda daha önceki öğrenilmiş olan bilgilerden yanlış öğrenme veya eksik öğrenilen bilgi varsa öncelikle bunların giderilerek yeni öğrenilecek olan bilginin bu bilgi üzerine inşa edilmesi gerekmektedir. Öğretmen soru sorarak açıklama yaparak tartışarak öğrencilerin önceki öğrenmelerle ilgili öğrenme eksikliklerini ve yanlışlarını ortaya çıkarabilir ve giderebilir (Gökalp, 2014). Öğrencilere bu ders için bir temel oluşturacak ilgi, ihtiyaç ve ön öğrenmeler nelerdir? sorusunun cevabı bu aşamanın gerekliliğini ve önemini ortaya koymaktadır. Yeni bir konuya geçmeden önce, son bir başlangıç etkinliği gereklidir. Çünkü öğrenme bir boşlukta meydana gelmez. Öğrenme ve öğretim sürecinde amaca uygun gerekli ön bilgiler kazanılmalı ve kullanıma hazır hale getirilmelidir (Kılıç, Babacan \& Padem, 2014).

Öğrencilere ön bilgilerin hatırlatılması yeni öğrenilen bilgiler ile sahip olunan bilgiler arasında köprü kurma görevini de yerine getirmektedir. Ausubel'e $(1963 ; 1968)$ göre öğrenenin mevcut bilişsel yapısı, yeni sunulan bilgilerin anlamlı bir şekilde öğrenilebilmesi ve unutulmaması için en önemli faktörlerden biridir. Yeni bir konu sunulmadan önce, öğrencilerin zihinsel yapıları yeni içerik için hazır olmalıdır. Yeni bilgiyi anlamlı olarak öğrenmede temel koşul, ön örgütleyicilere (düzenleyicilere) sahip olmaktır. Öğrenilecek içerikten önce sunulan ön örgütleyiciler, yeni sunulacak içeriği önceki bilgilerle ilişkilendirmeye ve bütünleştirmeye yarayan geniş bir iskeleti temsil eder. Ausubel, öğrenmenin kalıcı ve anlamlı olabilmesi için öğrencinin var olan bildikleriyle öğretime başlanmasının gerekliğini savunmaktadır. Ausubel, yeni öğrenilecek bilgi ile öğrencinin kendi bildikleri arasında köprü kurulmasının ön örgütleyiciler aracılığıyla sağlanabileceğini vurgulamış ve ön örgütleyicileri, yeni bilgiyle ilgili ama ondan daha soyut, kapsamlı ve genelleme düzeyindeki giriş nitelikli malzemeler olarak tanımlamıştır.

4. Uyarıcı materyalin sunulması (içeriği sunma / girdi / desenleme): Bu aşamada, ilgili dersin içeriğinin diğer bir deyişle o gün ilgili dersin amacına ulaştıracak materyalin, girdinin ve içeriğin farklı öğretim yöntem ve teknikleri aracılığıyla öğrencilere sunulmasıdır. Bir bakıma program geliştirmenin "içerik" ögesine denk gelmektedir. Kılıç, Babacan ve Padem (2014), sunulacak içeriğin özgün, seçici ve çeşitli olması konusuna dikkat çekmekte ve konuyu aşağıdaki gibi ele almaktadır:

a. Özgü̈nlük: Davranış öğretmek özgündür. Dersin içeriği öğrencilerin değerlendirilmelerinde, sonraki yıllarda ve sınıfın dışındaki dünyada kullanılabilecek bir yol olacak şekilde sunulmalıdır. Eğer amaç, öğrencilere mikroskobun parçalarını sınıflandırdıktan sonra tek hücreli canlıları tanımlamaları için mikroskop kullanmayı öğretmekse bu yol özgün olmayacaktır. Dersin bağlamını veya çok alakalı görülmeyen kısımlarını olabildiğince farklı hale getirerek öğretilen davranış daha özgündür. Bu şekilde gerçekleşen öğrenme sadece belirli bir durumla ilişkilendirilmeyip başka dersler ve ilerleyen kademelerde, derslerde ve sınıflarda da öğrencilerin karşılarına çıkabilecek durumlara uyarlanabilir. Aşağıdaki ifadeler öğrenci ilgisini konunun farklı yönlerine çekmek için uygun örneklerdir.

b. Seçicilik: Derse hazırlık aşamasında ve ders boyunca ikinci olarak ele alınması gereken en önemli nokta içeriğin ders için önemini vurgulamaktır. Derse hazırlık aşamasında öğrencilerinize "Sayfa 50 'de altta yer alan altı kavramı inceleyin" veya "3. Bolümün sonunda yer alan tablo ve figürlere bir göz atın" demek; ders işleme sürecindeyse "Bu önemli! Buraya dikkatinizi verin, Bu bilgi daha sonra size lazım olacak" gibi uyarılarda bulunmak seçiciliğe yardımcı olabilir. 
c. Çeşitlilik: Etkili öğretmenlerin başlıca davranılandan biri öğretimsel çeşitliliktir. Dersin başında öğrencilerin dikkatini toplamak önemlidir, fakat öğrencilerin dikkatlerini sürdürmeleri de ayrıca önemlidir. Öğretim tarzındaki çeşitlilik (görsel, dokunsal, sözel) ve öğretim etkinlikleri (grupla öğretim, soru-cevap, küçük grup tartışması vb.) öğrencilerin ilgi ve dikkatleri canlı tutar. Öğrencileri öğrenme sürecinde aktif ve dikkatli tutmanın yanı sıra çeşitlilik sağlamak bilinçli ve akılda kalıcı bir öğrenme tertibesini sağlar. Kısaca çeşitlilik Yeşilyurt'a (2019a; 2019b; 2013) göre dersleri öğrencilerin zekâ, ilgi, ihtiyaç, öğrenme stili, öğrenim kademesi ile dersin hedefleri, içerik ve öğrenme modeli vb. birçok değişkeni de dikkate alarak derslerin farklı öğretim yöntem ve teknikleriyle işlenmesinden geçmektedir.

5. Öğrenmeye yol gösterme (rehberlik etme): Bu basamak temelde bir öğretim aşaması olmayıp tüm aşamalarda geçerli olan önemli bir unsurdur. Öğretmenin rehberliği veya öğrenciye yol göstericiliği, esasında diğer öğretim aşamalarını da ilgilendirmektedir. Rehberlik, öğrencilerin öğrencilere $5 \mathrm{n} 1 \mathrm{k}$ sorusunun cevabını bulmalarında yol göstermek olarak ele alınmaktadır. Bu aşama bir öğretmenin mesleki anlamda çağdaş öğrenme ve öğretme modellerinde yer alan ve aynı zamanda günümüz öğretmen nitelikleri arasında da olan "rehberlik" rolüyle eşdeğerdir. Doğru kaynaklara ulaşma, neyi nereden çalışma, öğrenme sırasında nelere dikkat etme, uzun süreli belleğe anlamlı kodlama yapma vb. rehberlik aşamasının temel görevleri arasında yer almaktadır. Gagne'ne (1985) göre bu aşama, öğrencinin yeni bilgiyi uzun süreli belleğe anlamlı bir şekilde kodlaması için oldukça önemlidir. Gagne, Briggs ve Wager'a (1992) göre öğrenmeye rehberlik etmede şu yollara başvurulabilir:

$>$ Gerektiğinde öğretim desteği sağlamak.

$>$ Vaka çalışması, analog ve metaforlardan yararlanmak.

$>$ Durumla ilgili örnek olan ve olamayan örnekleri kullanmak.

> Kavram haritaları, rol oynama gibi çeşitli yöntemler kullanmak.

6. İstenilen davranışı (performans) ortaya çıkarma (anlamayı izleme): Her ders bilişsel, duyuşsal ve psiko-motor alanların ya birinde ya da birkaçında yer alan kazanımları (amaçları-hedefleri) öğrencilere kazandırmak amacıyla işlenmektedir. $\mathrm{Bu}$ durumda bir dersin nihai olarak sonucunda, öğrenciden bu alanların bir veya birkaç basamağında yer alan istenilen davranışları kazanması ve istedik davranış değişikliğine uğrayarak dersi tamamlamaları beklenmektedir. Bu durumda bir öğrencinin davranışlarında istendik yönde değiş̧iklik olması veya bunun gerçekleşmesinden bir öğretmenin emin olması bu basamağın temel özelliğini yansıtmaktadır. Gagne'ne (1985) göre öğretimin bu aşaması öğrencinin yeni bilgi veya beceriyi ne oranda ve hangi doğrulukta öğrendiğinin belirlenebilmesi için öğrenci tarafından gösterilmesini içermektedir. Kılıç, Babacan ve Padem (2014), bu aşamanın diğer genel karakteristik özelliğini şöyle izah etmektedir. "Öğrencilerin tamamlayacağı çekici ve öğrenmeye değer etkinlik ve görevler nelerdir?" sorusu bu aşamada sorulması ve cevaplanması gereken bir sorudur. Öğrencide istenilen davranışın ortaya çıkarılması veya öğrenmenin oluşmasından emin olmak için şu öneriler dikkate alınabilir:

$>$ Derse gelmeden önce çok sayıda sözel soru hazırlayın.

$>$ Öğrencilere ana noktalar ve öğretilen bolümler ile ilgili özetleyici sorular sorun.

$>$ Gönüllü öğrencilerin yanında el kaldırmayan öğrencilere de söz hakkı verin.

$>$ Öğrencilerden ilke ya da yöntemi kendi cümleleriyle açıklamasını isteyin.

$>$ Öğrencilerin arasında dolaşırken herkesin kendi cevabını yazmasını sağlayın.

$>$ Öğrencilerin kendi cevabını yanındaki arkadaşı ile karşılaştırmasını isteyin.

$>$ Bir sunumun / tartışmanın sonunda ana fikri tahtaya yazın, konuyu birlikte özetlemek üzere sinıfi ikiye ayırın.

7. Geri bildirim (dönüt) sağlama: Öğretme ve öğrenme sürecinde öğrencilerin ortaya koyduğu davranışların hemen ardından öğrenilen davranışın doğruluk ya da yanlışlık derecesi hakkında bilgi vererek öğrencinin neleri öğrendiği ve öğrenmesi gerektiğini bildirmektedir (Bloom, 1979). Dönüt sağlama öğrencinin neyi, ne kadar öğrendiği ve öğretmenin de öğretimsel faaliyetlerinin ne derece etkili 
olduğunu görmesi açısından önemlidir (Kaya, 2015). "Bu derste değerlendirici geri bildirimin sağlanması için kullanacağınız öğretim uygulamaları nelerdir?" sorusu bu ögenin temel sorusudur. Geri bildirim basamağı, istenilen davranışın ortaya çıkarılma basamağıyla yakından ilgilidir ve genellikle o etkinliği takip eder. Bilindiği üzere istenen davranışın ortaya çıkarılması öğrencilerin doğru cevabı vermek için üzerinde düşündüğü ve cevaba sarf ettiği içeriği öğrenmelerinde kolaylık sağlar. Yanıtlar ögrencileri öğrenmeye iten değerlendirmenin yapılmadığı hatırlama, özetleme, yeniden yorumlama veya problem çözme girişimleridir. Geri bildirim tüm sınıfa ya da farklı seviyelerde olan alt gruplara doğrudan yapılmadır. Örneğin; öğrencilere kendi fikirleri üzerine düşünme süresi verdikten sonra öğretmen doğru cevabı sınıfa verebilir, sonucun nereden geldiğini yüksek sesle okuyabilir. Fakat bireysel olarak geri bildirimde bulunmak daha önemlidir. Burada öğrenciye verilen yanı, öğrencinin yeteneği, tarih, dil ve kültür bilgisi ve eğer gerekli ise özel ihtiyaçları dikkate alınarak farklılaştırılmalıdır. "İyi deneme.”, "Bu sefer istediğim cevap için yeterli değil.”, ve "Biraz daha düşün.” gibi cevaplar öğrenciyi odaklandığı yanlış cevaptan, ceza almaksızın daha üretken ve öğrenciye bireysel geri bildirim vermeyi mümkün kılacak bir cevaba yöneltecektir. Öte yandan öğrencilerin yanlış cevaplarını gözden geçirmeleri için basit bir baş sallama veya gülümseme hareketi ile birlikte sınıfta dolaşılabilir (Kılıç, Babacan \& Padem, 2014). Etkili bir geri bildirim dört temel özelliğe sahip olmalıdır. Bunlar (Çelik, 2014):

a. Somutluk: Belirgin, açık ve net olmalıdır.

b. Anındalık: Öğrenenin tepkisinin hemen ardından verilmelidir.

c. Amaçlılık: Öğrenenin kendini düzeltebilmesi için gereken bilgiyi içermelidir. Amaç, öğrenenin yarar sağlaması ve gelişimidir.

d. Olumluluk: Geri bildirim öğrenen için olumsuz özellikler taşıdığı zamanlarda da olumlu bir yaklaşımla verilmelidir. Bu yaklaşım olumlu bir ses tonu ve üslup kullanılarak yapılabilir.

8. Davranışları (performansı-öğrenme ürünlerini) değerlendirme: Hedeflenen öğrenmenin gerçekleşip gerçekleşmediğinin, bir anlamda öğrenme ürününün değerlendirilmesidir. Bu bağlamda her bir öğrencinin istendik davranışı ne derecede kazandığının öğretme durumunun sonunda ortaya konulması gerekmektedir (Kaya, 2015). Bu öğretim basamağı, öğrencinin dersin hedeflerinde açıklanan istenen davranışı kazanma derecesinin değerlendirilmesini belirtir. Daha önce belirtildiği gibi, istenen davranışın ortaya çıkışı aniden ya da ertelenmiş (sözlü soru ya da ders kitabı etkinliği) veya değerlendirilen ya da değerlendirilmeyen (sınıfça ya da bireysel) bir süreç olabilir. Bu öğretim basamağ için, öncelikle değerlendirilen etkinliği tanımlamamız gerekir. Değerlendirme uygulamaları; puanlanmış mülakatlar, kompozisyon soruları, puanlanmış ev ödevleri, sınıf içi performansları ve öğrenci çalışma yapraklarını içerebilir. Öğretim amacı öğrencilerin anlamlı öğrenmenin bileşenleri olan buluş, keşfetme ve risk alma süreçlerini kısıtlamadan katılmaya teşvik olduğunda, bu formal (yasal, remi) değerlendirme işlemlerinin öğrenme sürecinin başlarında uygulanması öğrenmeyi zedeleyebilir. Fakat bu basamak öğrencilerin dersin bitiminde veya devam eden ilgili derslerde istenen bilgi, anlayış veya davranışı sergileyebilecekleri düzeyin değerlendirilmesinde etkili olabilir. Burada, bu etkinliği tamamlayıcı değerlendirme yöntemleri olarak ev, laboratuvar veya araştırma ödevleri, sunumlar, ürün dosyaları, test veya kısa sınavlar, bireysel veya sınıf içi uygulamalar, sözlü veya kompozisyon soruları, performans değerlendirme kullanılabilir (Kılıç, Babacan \& Padem, 2014):

9. Kalıcılı̆̆ı sağlama (hatırlama) ve transferi güçlendirme: $\mathrm{Bu}$ aşama, çeşitli durum ve örneklerle ek alıştırmalar, uygulamalar yapmayı gerektirir. Öğrenilen bilgilerin geri getirilmesi ve yeni durumlarda kullanılmasında aralıklı gözden geçirme etkili olmaktadır. Bu bağlamda bilgiyi hatırlamak ve yeni durumlarda kullanmak için aralıklı gözden geçirmede uygun aralıkları belirlemek önemlidir. Öğrenme gerçekleştikten hemen sonra öğrenciye öğrenmeyi güçlendirici nitelikte alıştırma ve ödevler verilmelidir. Bu alıştırma ve ödevlerin başlangıç öğrenmesini izleyen aynı gün ve hafta içerisinde yapılması daha fazla yararlıdır. Çünkü aralıklı yapılan gözden geçirme öğrenilen bilginin kalıcılığını, hatırlanmasını ve transferini güçlendirmektedir. Ancak aralıklı gözden geçirme ve alıştırmaların, 
örneklerin, çözülecek problemlerin yeni olmasına dikkate edilmelidir (Senemoğlu, 2010; Kaya, 2015). Öğrenilen bilgilerin transfer edilebilmesinde en iyi yol, öğrencinin öğrendiklerini kullanabileceği, öğrenme sırasında etkileşimde bulunduklarından farklı, yeni ve çeşitli örnekler ve durumlarla karşı karşıya gelmesidir (Gagne, Briggs \& Wager, 1992).

Öğretim durumları modelinde yer alan ve yukarıda dile getirilen bu öğretim etkinliklerinin sırası değişebilir. Bu bağlamda bazı durumlarda öğretim etkinliklerinin ardışık sırası değişebileceği gibi bazı durumlarda bir öğretim etkinliği başka bir öğretim etkinliğinin işlevini de yerine getirebilir. Öğretim durumları modelinin uygulanabilmesi insan zihninde meydana gelen süreçlerin iyi bilinmesine bağlıdır. Gagne'ne göre öğretme sürecinde yer alması gerekli (dışsal) muhtemel olaylar ile insanın içinde oluşan (içsel) öğrenme süreçleri arasında bir ilişki bulunmaktadır. Tablo 2'de etkili bir derste yer alan öğrenme aşamaları ve bu öğrenme süreçlerini sağlayacak öğrenme etkinliklerinin neler olması gerektiği aşamalı olarak açıklamıştır. Buna göre içsel öğrenme süreçleri ve bu süreçleri destekleyen dışsal öğretim etkinlikleri aşağıdaki tabloda sunulmuştur (Senemoğlu, 2010).

Tablo 2: Öğretim Durumları Modeline Göre Etkinlik ve Süreç Aşamaları

\begin{tabular}{|c|c|c|c|}
\hline $\begin{array}{c}\text { Öğretim } \\
\text { Etkinlikleri } \\
\text { (Dışsal } \\
\text { olaylar/faktörler) }\end{array}$ & $\begin{array}{l}\text { Öğrenme Süreçleri } \\
\text { (İçsel } \\
\text { olaylar/faktörler) }\end{array}$ & Amaç & Özellikler \\
\hline \multirow[t]{2}{*}{$\begin{array}{l}\text { Dikkati sağlama } \\
\text { (dikkat çekme) }\end{array}$} & $\begin{array}{l}\text { Öğreneni tetikte } \\
\text { bulundurma. }\end{array}$ & \multirow{2}{*}{$\begin{array}{l}\text { Öğrencinin } \\
\text { uyarıcıları } \\
\text { algılamasını } \\
\text { sağlamak. }\end{array}$} & $\begin{array}{l}\text { Ses değişimleri, öğrenciye } \\
\text { ismiyle seslenme, 1şı durumu. }\end{array}$ \\
\hline & $\begin{array}{l}\text { Sinir titreşimlerinin } \\
\text { akımlarının alınması }\end{array}$ & & $\begin{array}{l}\text { Öykü ve fikra anlatma. harita } \\
\text { sunma, }\end{array}$ \\
\hline \multirow{2}{*}{$\begin{array}{l}\text { Hedeften haberdar } \\
\text { etme }\end{array}$} & Beklentiyi karşılama. & \multirow{2}{*}{$\begin{array}{l}\text { Öğrenciye öğrenme } \\
\text { amacını bildirmek. }\end{array}$} & \multirow{2}{*}{$\begin{array}{l}\text { Öğrenciye neyi öğreneceğini, } \\
\text { öğrendikleri bilgileri nerede ve } \\
\text { nasıl kullanacağını söyleme. }\end{array}$} \\
\hline & $\begin{array}{l}\text { Yönetici-kontrol } \\
\text { mekanizmasın harekete } \\
\text { geçirilmesi, beklenti. }\end{array}$ & & \\
\hline \multirow{2}{*}{$\begin{array}{l}\text { Önceki (ön koşul) } \\
\text { öğrenmelerin } \\
\text { hatırlatılması } \\
\text { (gözden geçirme) }\end{array}$} & $\begin{array}{l}\text { Kısa süreli belleğe } \\
\text { getirme. }\end{array}$ & \multirow{2}{*}{$\begin{array}{l}\text { Önkoşul } \\
\text { öğrenmeleri } \\
\text { kullanıma hazır } \\
\text { hale getirmek. }\end{array}$} & \multirow{2}{*}{$\begin{array}{l}\text { Yeni bilgileri öğretmenden önce } \\
\text { önceden öğrenilenleri işleyen } \\
\text { (kısa süreli) belleğe geri getirerel } \\
\text { hatırlatma. }\end{array}$} \\
\hline & $\begin{array}{l}\text { Önceki bilgileri uzun } \\
\text { süreli bellekten geri } \\
\text { getirme. }\end{array}$ & & \\
\hline \multirow{2}{*}{$\begin{array}{l}\text { Uyarıcı materyalin } \\
\text { sunulması (içeriği } \\
\text { sunma / girdi / } \\
\text { desenleme) }\end{array}$} & $\begin{array}{l}\text { Seçici algılamayı } \\
\text { kolaylaştırma. }\end{array}$ & \multirow{2}{*}{$\begin{array}{l}\text { Yeni bilgi } \\
\text { öğrenmesini } \\
\text { sağlamak. }\end{array}$} & \multirow{2}{*}{$\begin{array}{l}\text { Öğrenilecek hedef-davranışlarla } \\
\text { ilgili uyarıcılar kullanma (işitsel } \\
\text { görsel, sembol, nesne,,model, } \\
\text { gösteri, benzetim ortam ve } \\
\text { araçlar, çizgi film, örnek insan } \\
\text { modelleri, ögretim konusuna } \\
\text { uygun hareketli filmler vb.) }\end{array}$} \\
\hline & $\begin{array}{l}\text { Seçici algı için önemli } \\
\text { noktaların görülmesi. }\end{array}$ & & \\
\hline \multirow{2}{*}{$\begin{array}{l}\text { Öğrenmeye yol } \\
\text { gösterme } \\
\text { (rehberlik) }\end{array}$} & Bilgiyi kodlama. & \multirow{2}{*}{$\begin{array}{l}\text { Öğrencinin bilgiyi } \\
\text { kodlamasına } \\
\text { yardım etmek ve } \\
\text { uzun süreli belleğe } \\
\text { aktarmasını } \\
\text { sağlamak. }\end{array}$} & \multirow{2}{*}{$\begin{array}{l}\text { Öğrenilen bilgileri uzun süreli } \\
\text { belleğe anlamlandırarak aktarma. } \\
\text { İpuçları vererek geçici yardım } \\
\text { sağlayarak cevabı ögrencinin } \\
\text { kendisi tarafindan bulmasını } \\
\text { sağlama. }\end{array}$} \\
\hline & $\begin{array}{l}\text { Bilgiye anlam verme } \\
\text { ve kodlama sürecinin } \\
\text { çalıştırılması. }\end{array}$ & & \\
\hline
\end{tabular}




\begin{tabular}{|c|c|c|c|}
\hline $\begin{array}{l}\text { İstenilen davranışı } \\
\text { (performans) ortaya } \\
\text { çıkarma }\end{array}$ & $\begin{array}{l}\text { Tepkide bulunma. } \\
\text { Davranış } \\
\text { oluşturucuların } \\
\text { harekete geçirilmesi, } \\
\text { tepkide bulunma. }\end{array}$ & $\begin{array}{l}\text { Öğrenmenin } \\
\text { oluşmasından emin } \\
\text { olmak. }\end{array}$ & $\begin{array}{l}\text { Öğrenme konusuyla ilgili } \\
\text { davranışı (kazanımı) ortaya } \\
\text { çıkarma. }\end{array}$ \\
\hline $\begin{array}{l}\text { Geri bildirim } \\
\text { (dönüt) }\end{array}$ & $\begin{array}{l}\text { Geri besleme. } \\
\text { Pekiştirmeyi } \\
\text { oluşturma, tepkiyi } \\
\text { güçlendirme }\end{array}$ & $\begin{array}{l}\text { Öğrenciye } \\
\text { öğrenmesi hakkında } \\
\text { bilgi vermek. }\end{array}$ & $\begin{array}{l}\text { Öğrenmeyle ilgili olan } \\
\text { davranışların hemen ardından } \\
\text { ilgili davranışın doğru veya } \\
\text { yanlışlığına iliş̧kin öğrenciyi } \\
\text { bilgilendirme. } \\
\text { Doğru davranışları pekiştirme } \\
\text { (çok güzel, aferin). Yanlış bilgi } \\
\text { veya cevapları düzeltmek için } \\
\text { yeni uyarıcılar (ipuçları) verme. }\end{array}$ \\
\hline $\begin{array}{l}\text { Davranışları } \\
\text { (performansı, } \\
\text { öğrenme ürünlerini) } \\
\text { değerlendirme }\end{array}$ & $\begin{array}{l}\text { Kazanımların düzeyini } \\
\text { ve derecesini belirleme. } \\
\text { Dönüt mekanizmasını } \\
\text { harekete geçirme ve } \\
\text { pekiştirmeyi mümkün } \\
\text { kılma. }\end{array}$ & $\begin{array}{l}\text { Öğrencinin güven } \\
\text { kazanmasını } \\
\text { sağlamak. }\end{array}$ & $\begin{array}{l}\text { Öğrenme öge, konu veya } \\
\text { davranışlarla ilgili beceri, bilgi ve } \\
\text { tutumları yoklama. }\end{array}$ \\
\hline $\begin{array}{l}\text { Kalıcılığı sağlama } \\
\text { ve transferi } \\
\text { güçlendirme }\end{array}$ & $\begin{array}{l}\text { Hatırlama ve transferi } \\
\text { sağlama. } \\
\text { Geri getirme } \\
\text { mekanizması için } \\
\text { ipuçları ve stratejiler } \\
\text { sağlama ve harekete } \\
\text { geçirme. }\end{array}$ & $\begin{array}{l}\text { Ek alıştırma ve } \\
\text { uygulamalarla } \\
\text { kalıcılığı sağlamak. }\end{array}$ & $\begin{array}{l}\text { Yeni öğrenilen bilgileri } \\
\text { güçlendiren örneklendirme, } \\
\text { alıştırma, proje ve ödevler verme. } \\
\text { Bu etkinlikleri öğrenme ve } \\
\text { öğretim sürecini izleyen aynı gün } \\
\text { ve hafta içerisinde yaptırma. }\end{array}$ \\
\hline
\end{tabular}

Kaynak: Akpınar (2012), Senemoğlu (2010), Karaağaçlı ve Erden (2008)'den uyarlanmıştır.

Gagne'ne göre öğrenme, ardışık olan birçok sürecin sonucunda oluşmaktadır. Ancak bazı süreçler aynı anda veya eş zamanlı olarak gerçekleştiğinden bu süreçlerin sırası zamanla değişebilir ki bu süreçlere öğrenmenin içsel süreçleri denir. Bu modele göre öğrenme, içsel süreçler ve dışsal olayların birlikteliğiyle meydana gelmektedir. Öğrenmenin içsel süreçleri, çevrede yer alan uyarıcıları kapsayan dışsal olaylar tarafından etkilenmektedir. Hedeflere yönelik öğrenmeyi desteklemek üzere dışsal etkinliklerin planlanması, sürdürülmesi ve değerlendirilmesine de öğretim denir. Öğretmen bir öğretim yöneticisidir ve bu bağlamda görevi ise hedefler doğrultusunda ve öğrenme süreçlerine uygun olarak dışsal olayları seçme, organize etme, düzenleme ve denetlemedir. Bu noktada içsel olarak güdülenmiş, kendi öğrenmesini yine kendi yönlendirebilen öğrenciler için her zaman dişsal etkiye gerek kalmayabilir. Ancak eğitim sürecinde, neredeyse tüm öğrencilerin kapasitelerini tam kullanabilmeleri için dişsal etkinliklerle desteklenmesi önemlidir. Bu nedenle, bir dersi planlamada dikkate alınması ve öncelik verilmesi gereken en önemli nokta, içsel öğrenme sürecinin her birini en üst düzeyde destekleyecek dışsal öğretim etkinliklerini düzenlemek ve bu etkinlere yer vermektir (Akpınar, 2012; Senemoğlu, 2010). 


\section{B) Öğrenme Kategorileri (Çeşitleri-Türleri-Hiyerarşisi)}

Gagne'ne göre öğrenme birbiriyle ilişkili sekiz kategoriden oluşan bir süreçtir. Öğrenme kategorilerinin en basit öğrenme çeşidinden en karmaşı öğrenme çeşidine göre sıralaması ve özellikleri şöyledir (Kaya, 2015; Yeşilyaprak \& Uçar, 2012):

1. İşaret öğrenme: Öğrenmenin en alt basamağıdır. Birey, uyarıcılara tepki geliştirmeyi öğrenir. Klasik koşullanma düzeyinde bir öğrenmedir. Çocuğun sesin, ışığın, rengin farkına varmasında olduğu gibi.

2. Uyarıcı davranış (tepki) bağını (ilişkisini) öğrenme: Kişi bu basamakta uyarıcıyla davranım arasındaki bağı öğrenir. Operant (edimsel) koşullanma türünde bir öğrenmedir. Kırmızı ışık yanınca durmada olduğu gibi.

3. Uyarıcı davranım (tepki) bağlarını kurarak uyarıcı-davranım (tepki) zincirlerini oluşturma (basit zincirleme): Bu basamakta kişi zincirleme davranımlar oluşturur. Uyarıcı davranım arasındaki ilişkiyi, belli bir sıra içinde öğrenme. Arabayı çalıştırma ve sürmede olduğu gibi.

4. Sözlü karşılıklarıyla uyarıcı-davranım zincirlerini öğrenme (sözel ilişkilendirme): $\mathrm{Bu}$ öğrenme, kelimelerle anlamlar arasında bağ kurmaya işaret eder, sembolleri öğrenme ile ilgilidir. Sözcüklerin anlamlarını öğrenme ve iki sözcük arasında ilişki kurmada olduğu gibi. Örneğin: Kelimelerin (kelime gruplarının) anlamlarını öğrenmek, şiir ezberlemek.

5. Ayırt etmeyi öğrenme: Öğrenen bu basamakta ilişkileri, nesneleri, hayvanları, olguları birbirinden ayırt eder, uyarıcılar arasındaki farkları öğrenir. Farklı uyarıcıya farklı davranmadır. Anneyi babadan, kediyi köpekten, masayı sandalyeden ayırt etmede olduğu gibi.

6. Kavram öğrenme: Bu basamakta öğrenen; kavramların ne anlama geldiğini öğrenir, benzer özelliklerden bir grup oluşturur. Belli ölçütlere göre obje, olay ve nesneleri gruplayabilmedir. Pekiştireç, okul, devlet, öğretim, eğitim gibi kavramların anlamlarını bilme gibi.

7. İlke (genelleme) öğrenme: Kavramlar arasındaki ilişkileri, neden-sonuç, öncelik-sonralık bağlarını öğrenen bu basamakta öğrenir. Yol gösterici ve problem çözmeye yarayan bilgiler edinmedir. Kanun, kuram, ilke, sayıltı, genellemelerin nerede ve nasıl kullanılacağını bilmede olduğu gibi. Örneğin: Üçgenin alanının yükseklikle taban uzunluğunun çarpımının yarısı olduğunu öğrenmek.

8. Problem çözme: En üst düzeyde öğrenmedir. Kişi bu basamakta ilgili kanun, ilke, kural, genellemeleri kullanarak bir problemi çözmeyi öğrenir. İlkeleri kullanarak değişik durumlarda problem çözme becerisine işaret eder. Örneğin: Öğrenilen ilkeleri bir problemin çözümünde kullanma. Fizik, matematik, kimya, biyoloji, sosyoloji, felsefe vb. alanlarda verilen problemleri çözmede olduğu gibi.

Öğrenme türlerinin ilk beşi davranışçı modele dayalı olup birincisi klasik koşullanma diğerleri ise edimsel koşullanmayla açıklanabilir. Gagne; özellikle son dört öğrenme türü üzerine odaklanmış olup kavram öğrenmenin ayırt edebilmeyi, ilke öğrenmenin ilkeyle ilgili kavramları bilmeyi, problem çözmenin ise sorunla ilgili ilke ve kavramları bilmeyi gerekli kıldığını vurgular. Bu nedenle ona göre öğrenme, birikimler sonucu gerçekleşmektedir (Gündüz, 2010).

\section{C) Öğrenme Ürünleri (Çıktıları)}

Gagne, Briggs ve Wager (1992) tarafindan yapılan sinıflandırmaya göre öğretim durumları modeline göre öğrenme ürünleri beş tür de ele alınmaktadır (Driscoll, 2005). Bu sinıflamada yer alan öğrenme ürünleri ve özellikleri şöyle açıklanabilir (Akçay, 2011; Donmuş Kaya, 2018; Driscoll, 2005; Gökalp, 2014; Olkun \& Toluk Uçar, 2014):

a. Sözel bilgi: İfade etmeye veya açıklamaya dönük bilgidir. Olgular, kavramlar, ilkeler gibi önceden öğrenilmiş konulardır. Bilişsel alandaki bilgi basamağının karşılığı olan bu basamaktaki 
bilgiler kendimizi ifade etmemizi sağlayan ve günlük yaşamda kullanılan pratik bilgileri kapsamaktadır. Öğretim sürecinde daha çok "ne?" sorusunun cevabı ile ilgili olup olgusal bilgilerle alakalıdır. "Stresin ana belirtilerini listeleme, gelişim ilkelerini söyleme" hedefleri örnek gösterilebilir.

b. Zihinsel (entelektüel-bilişsel) beceriler: Sözel bilgi "şunu” bilme iken zihinsel beceriler "nasıl” 1 bilme ile ilgilidir. Diğer bir deyişle üst düzey öğrenme olarak nitelendirilebilecek zihinsel beceriler daha çok "nasıl" sorusunun cevabının karşıllı̆ını oluşturmaktadır. Kazanılan bilgilerin birleştirilmesi başka biçime dönüştürülmesi ve birbiriyle ilişkilendirilmesini kapsamaktadır. Bu model okullarda öğrenilen en önemli davranışın entelektüel beceriler olduğunu ileri sürmektedir. Entelektüel beceriler kendi içerisinde beş alt gruba ayrılmaktadır.

1. Ayırt etme: Nesneleri biçimleri ya da şekilleri ayırma şeklinde tanımlanabilir. Örnek hedefler (kazanımlar) olarak "iki fabrikasyon kumaş arasındaki farkı söyleme, objeleri büyükten küçüğe doğru sıralama" verilebilir.

2. Somut kavramlar: Somut nesneler olgular ya da biçimlerin sınıflarını belirleyebilme olarak tanımlanmaktadır. "Bir alet kutusuna tüm aletleri düzenli yerleştirme, nesneleri belli ölçütlere göre sınıflama" hedefleri örnek gösterilebilir.

3. Tanımlanmış kavramlar: Olgular ya da fikirlerin tanımlarını yeni örnekler ile sınıflandırma şeklinde tanımlanmaktadır. Hedeflere ise "verilen örnekleri, ölçüte göre sınıflama, öğrenme ürünlerine uygun örnekler verme" örnek verilebilir.

4. Kurallar: Bir problem sınıfını çözmek için tek bir ilişkiyi uygulamak olarak tanımlanabilir. "Bir sınıfın yaş ortalamasını hesaplamak, formüle göre zekâ bölümünü hesaplamak" şeklinde hedef örnekler sunulabilir.

5. Çoklu (üst düzey) kurallar (ilkeler): "Karmaşık bir problemin çözümü için kuralların yeni bir kombinasyonunu yapma" olarak tanımlanmaktadır. Hedef örnekler olarak "bir örgütteki temel bir değişimi başarmak için plan oluşturma, bir ders planı geliştirme" gösterilebilir.

c. Bilişsel stratejiler: Gagne'nin tanımladığı beceriler arasında "bilişsel stratejiler" belki de anlaşılması en güç olanıdır. Bilişsel stratejiler, bireyin kendi öğrenme haritasının farkında olması ile ilişkilidir. Bilişsel stratejiler; bireyin dikkatine, düşünmesine, öğrenmesine ve öğrendiklerini hatırlamasına rehberlik eder. Kendini izleme ve rehberlik etme becerisi daha çok zihinsel becerileri etkili bir şekilde kazanmaya ve kullanmaya yardım eder. Öğrencinin öğrenmesine, dikkatine, hatırlamasına ve düşünmesine rehberlik yapar. "Öğrenmeye yardım için düşünme, hissetme ve eylem gibi kişisel yolları işe koşma" olarak tanımlanmaktadır. Öğrencinin kodlama, dikkat etme, geriye getirme, problem çözme ve transfer için çeşitli stratejileri öğrenmesi, bağımsız öğrenciler ve bağımsız düşünürler yetiştirmek açısından önemlidir. Sentez basamağındaki bilgilerdir. "Müşteriye sunulan görsel uyaranları bütünleştirme, güneş enerjisinden yararlanmak için yeni yollar önerme" hedefleri örnek verilebilir.

d. Tutumlar: Tutumlar bireyin herhangi bir şeye karşı olumlu ya da olumsuz davranışlarını etkileyen içsel süreçtir. Anlama ve duyguların içsel durumlarına dayanan kişisel eylemleri seçme şekilde tanımlanabilir. Duyuşsal davranış özelliği taşıyan bu basamakta birey sevme, önemseme, kabul etme, yardım etme, değer verme, sorumlulukları yerine getirme, hoşlanma vb. davranışları içermektedir. "Kitapçıdaki çeşitli türdeki romanlar arasından savaş romanı seçme, tiyatroya gitmekten hoşlanma" hedefleri örnek gösterilebilir.

e. Motor (devinişsel) beceriler: Zihin-kas koordinasyonunu gerektiren öğrenmelerdir. Kasların kullanımını gerektiren etkinlikleri yerine getirme olarak tanımlanabilir. Genetik özelliklerden ziyade öğrenilmiş fiziksel aktiviteler (performans) anlamındadır. Bir işin yapılması sırasında bilinçli zihinsel etkinliğin yönlendirilmesiyle oluşan koordineli fiziksel hareketlerdir. "Müzik aleti çalma, bisiklet kullanma, güzel yazı yazma" hedefleri örnek gösterilebilir.

Gagne'nin çağdaşı olan Benjamin Bloom insanların öğrenme kapasitelerini bilişsel, duyuşsal ve psiko-motor olarak üç ana alandan oluştuğunu belirtmiştir. Bu sınıflama günümüze kadar Krathwohl, 
Bloom, Masia, Simpson, Reigeluth'a katkılarıyla revize edilmiş ve bu sınıflama günümüze kadar kabul edilebilirliğini devam ettirmiştir (Yeşilyurt, 2012). Öğretim durumları modeli bu üç alanı da kapsayan, bütünleştirilmiş bir taksonomi sunan tek öğretim modeli olarak karşımıza çıkmaktadır. Nitekim sözel bilgi, zihinsel (entelektüel-bilişsel) beceriler ve bilişsel stratejiler bilişsel alanı; tutumlar duyuşsal alanı; motor beceriler ise piso-motor alanı temsil etmekte veya bu alanlarda yer alan davranışları (kazanımları, hedefleri vb.) içermektedir.

\section{Öğrenme Ürünlerinin Kazanımını Etkileyen Koşullar}

Gagne; bilgiyi işleme modelini, kendi modeline bir temel olarak kabul ettiği için öğrenme koşulları hem içsel olayları (önceden kodlanmış bilgi gibi) hem de dış olayları (kodlamayı kolaylaştırmak için detaylandırma yöntemleri) içermektedir. Öğretim durumları modeline göre sınıflandırılan öğrenme ürünlerinin hangi koşullar altında oluşacağı Gagne (1985), Gagne ve Medsker (1996), Gagne ve Driscoll (1988) tarafından ele alınmıştır. Öğrenme çıtılarını etkileyebilen dış koşullara Tablo 3’te yer verilmiştir (Driscoll, 2005).

Tablo 3: Öğrenme Çıktılarını Kritik Etkileyen Dış Koşullar

\begin{tabular}{ll}
\hline Öğrenme Çıktıları & Eleştirel Öğrenme Koşulları (Dış Koşullar) \\
\hline Sözel Bilgi & İstiflenmesi için bilgiyi verin. \\
& Etkili hatırlama ve bilgi genellemesi için ipuçları verin. \\
& Bilginin etkili kodlanması için, anlamlı bir içerik (bağlam) sağlayın. \\
& Baskı ya da konuşma değişimleri ile ayırt edici özelliklere dikkati çekin. \\
\hline Zihinsel Beceriler & Ayırt edici özelliklere dikkati çekin. \\
& İşleyen belleğin sınırları içinde kalın. \\
& Transferi desteklemek için çeşitli içerikler kullanın. \\
& Uygulama ve aralıklı gözden geçirme için firsatlar düzenleyin. \\
& Daha önce öğrenilmiş bileşen becerileri hatılımaya teşvik edin. \\
& Bileşen becerilerin sıralanması ya da kombinasyonu için sözel ipuçları verin. \\
\hline Bilişsel stratejiler & Stratejiyi tanımlayın ya da gösterin. \\
& Stratejiyi kullanan uygulaması için çeşitli durumlar sağlayın. \\
& Çıktı ya da stratejinin özgün ya da yaratıcılığı gibi bilgilendirici dönüt verin. \\
\hline İstenen tutumla ilgili bir başarı beklentisi oluşturun. \\
& İletişim ya da kişisel eylem tercihi gösterisini düzenleyin. \\
& Beğenilen bir insan modeli ile öğrencinin kimliğini oluşturmasını sağlayın. \\
& Başarılı performanslar için geri bildirim verin ya da dönüt gözlemine izin verin. \\
\hline Tekrarlanan uygulamalar düzenleyin. \\
Zihinsel uygulama kullanımını teşvik edin. \\
Performansın doğruluğuna ilişkin anında dönüt verin. \\
Yürütme alt programına ipucu vermesi için sözel ya da diğer rehberlikleri sunun. \\
\hline Motor beceriler
\end{tabular}

Kaynak: Gagne ve Driscoll (1988)'den uyarlayan Driscoll, 2005. 


\section{Sonuç}

Öğretim ve öğrenme modelleri, eğitim sistemlerine yön veren temel belirleyicilerden biridir. Geleneksel öğrenme, davranışçı öğrenme, bilişsel öğrenme, bilgiyi işleme, probleme dayalı öğrenme, proje tabanlı öğrenme, tam öğrenme, programlı öğretim, modüler öğretim, çoklu zekâya dayalı öğrenme, okulda öğrenme modelleri tarihsel süreç içerisinde eğitim sitemlerini en fazla etkileyen öğretim ve öğrenme modelleri arasında yer almaktadır. Öğretim modelleri içerinde yer alan "öğretim durumları modeli" de eğitim sistemlerini etkilemiş olup bir takım tartışmalara rağmen günümüzde dahi hâla en çok kullanılan öğretim modellerinden biri olmuştur. Gagne tarafından geliştirilen öğretim durumları modeli davranışçı, bilişsel ve bilgiyi işleme modellerinden etkilenmiş ve bu modellerin en genel özelliklerini bir bakıma sentezlemiştir. Bu bakımdan özgün olan ve aynı zamanda öğretim sürecinin genel ilkelerine uygun olan öğretim durumları modeli öte yandan bir dersin giriş, gelişme ve sonuç bölümlerinin genel hatlarını da ortaya koymuştur. Özellikle ülkemizde adı bilinmese dahi bu model, ders planlarının yapılmasında, derslerin işlenme basamaklarının belirlenmesinde ve takip edilmesinde öğretmenler tarafından en çok kullanılan öğretim modellerinden birisi olmuştur. Durum böyle iken alanyazında öğretim durumları modeline yeteri kadar yer verilmediği, yer veren kaynaklarda modelin teorik temellerinin (özelliklerinin, uygulama şeklinin vb.) yüzeysel olarak ele alındığı görülmektedir. Öğretim durumları modeli temelde öğrenme aşamaları, öğrenme kategorileri (çeşitleri-türlerihiyerarşisi) ve öğrenme ürünleri (çıktıları) olmak üzere üç ana bileşenden oluşmaktadır. Bu çalışma kapsamında ulaşılan kaynaklarda öğretim durumları modeliyle ilgili olan bilgiler derlenmiş, bir araya getirilmiş, teorik (kuramsal) temelleri ve temel bileşenleri (öğrenme aşamaları, öğrenme kategorileri ve öğrenme ürünleri) bir bütünlük içerisinde açıkça ve detaylı bir şekilde "öğretim durumları modeli öğretmen el kitabı" niteliğinde açıklanmıştır. Bu bakımdan çalışmanın hem alanyazına hem de öğretimöğrenme sürecinin temel ögesi olan öğretmenlere uygulamada katkı sağlayacağı umulmaktadır.

\section{KAYNAKÇA}

Akçay, A. (2011). Web macerası öğretim yönteminin Gagne'nin öğretim durumları modeline uygunluğu, Ĕ̆itim Teknolojileri Araştırmaları Dergisi, 2(1), 1-11.

Akınoğlu, O. (2008). Öğretim ilke ve yöntemleri (Ed. Ş. Tan), Öğretim kuram ve modelleri (ss. 131179), Ankara: Pegem Akdemi.

Akpınar, B. (2012). Eğitim programları ve öğretim, Ankara: Data Yayınları.

Alkan, C. (2005), Eğitim teknolojisi, Ankara: Anı Yayıncılık.

Ausubel, D. P. (1963). The psychology of meaningful verbal learning, New York: Grune \& Stratton.

Ausubel, D. P. (1968). Educational psychology: A cognitive view, New York: Holt, Rinehart and Winston.

Bakırcıŏlu, R. (2012). Ansiklopedik eğitim ve psikoloji sözlüğü, Ankara: Anı Yayıncılık.

Baş, G. (2012). Gagne'nin öğretim etkinlikleri modelinin öğrencilerin akademik başarılarına ve İngilizce dersine yönelik tutumlarına etkileri, Uludă̆ Üniversitesi Ĕ̈itim Fakültesi Dergisi, 25 (2), 433-457.

Bloom, B. S. (1979). İnsan nitelikleri ve okulda öğrenme (Çev: D. A. Özçelik; 2016), Ankara: Pegem Akademi.

Çelik, M. (2014). Eğitim psikolojisi el kitabı (Ed. R. Ç. Eroğul \& F. Yurtal), Öğrenme ve öğrenmeyi etkileyen faktörler (ss. 309-326), Ankara: Mentis Yayıncılık. 
Donmuş Kaya, V. (2018). Öğretim etkinlikleri modeli’ne dayal çevrimiçi ögrenme ortamının ögrencilerin akademik başarılarına, tutumlarına ve ögrenmede kalıcılı̆̆a etkisi, Doktora tezi, Frrat Üniversitesi.

Driscoll, M. P. (2005). Psychology of learning for instruction (Öğretim süreçleri ve öğrenme psikolojisi; Çev. Ö. F. Tutkun, S. Okay \& E. Şahin; 2012), Ankara: Anı Yayıncılık.

Duman, B. (2007). Süreç temelli öğrenme-öğretim modeli, Muğla Üniversitesi Sosyal Bilimler Enstitüsü Dergisi, (19), 37-61.

Eşgi, N. \& Arslan, Ö. (2015). Öğretim tasarımı üzerine bir söyleşi: Robert Gagne ve David Merrill, No: 1-2, Akademik Sosyal Araştırmalar Dergisi, 3(21), 561-589.

Fidan, N. (2012). Okulda ögrenme ve öğretme, Ankara: Pegem Akademi.

Gagne, R. M. \& Driscoll, M. P. (1988). Essentials of learning for instruction, Englewood Cliffs, NJ: Prentice-Hall.

Gagne, R. M. \& Medsker, K. L. (1996). The conditions of learning: Training applications, Fort Worth: Harcourt Brace College Publishers.

Gagne, R. M. (1985). The conditions of learning and theory of instruction, New York: Holt, Rinehart \& Winston.

Gagne, R. M., Briggs, L. J. \& Wager, W. W. (1992). Principles of instructional design, Fort Worth: Harcourt Brace Jovanovich.

Gökalp, M. (2014). Öğrenme, öğretme kuram ve yaklaşımları (Ed. B. Oral), Öğretme-öğrenme modelleri (ss. 325-349), Ankara: Pegem Akademi.

Gündoğdu, K. (2016). Öğrenme - öğretme kuramları ve uygulamadaki yansımaları (Ed. G. Ekici), Gagne'nin ögretim durumları modeli (ss. 347-371), Ankara: Pegem Akademi.

Gündüz, M. M. (2010). İlköğretim din kültürü ve ahlâk bilgisi V. sinıf ders kitabının Gagne’nin ögretim ilkelerine göre içerik açısından incelenmesi, Yüksek lisans tezi, Selçuk Üniversitesi.

Gündüz, Ş. (2002). Illköğretim 6. sinıffen bilgisi dersinde Gagne'nin öğretim etkinlikleri modeline göre hazırlanmış bilgisayar destekli öğretim uygulamasının öğrencilerin başarı düzeylerine etkisi, Yüksek lisans tezi, Selçuk Üniversitesi.

Güneş, F. (2014). Öğretim ilke ve yöntemleri (Ed. F. Güneş), Tanım ve kavramlar (ss. 1-22), Ankara: Pegem Akademi.

İlhan Beyaztaş, D., Kapt1, S. B. \& Gelbal, S. (2013). Ortaöğretim ve özel dershane öğretmenlerinin öğretme-öğrenme sürecindeki davranışlarına ilişkin öğrenci görüşleri, Uluslararası Eğitim Programları ve Öğretim Çalışmaları Dergisi, 3(5), 1-10.

Karaağaçlı, M. \& Erden, O. (2008). İnternet destekli uzaktan eğitimde dokuz aşamalı öğretim durumunun tasarımı, Bilişim Teknolojileri Dergisi, 1(2), 21-29.

Kaya, M. F. (2015). Öğretim ilke ve yöntemleri, Semra Güven \& Mehmet Arif Özerbaş (Ed.), Öğretmeögrenme stratejileri ve modelleri (ss. 179-236), Ankara: Pegem Akademi Yayınları.

Kılıç, A., Babacan, T. \& Padem, S. (2014). Araştırma temelli etkili öğretim yöntemleri, (Çev. Ed. B. Acat), Ünite ve ders planlama (ss. 160-202), Ankara: Nobel Akademik Yayınc1lık.

Menzi, N. (2012). Gagne'nin ögretim durumları modeli'ne göre hazırlanan internet temelli öğretim uygulamasının ilköğretim bilişsim teknolojileri dersinde öğrencilerin akademik başarılarına ve kalıcılığa etkisi, Yüksek lisans tezi, Çukurova Üniversitesi. 
Olkun, S. \& Toluk Uçar, Z. (2014). İlköğretimde etkinlik temelli matematik öğretimi, Ankara: Eğiten Kitap.

Özbek, R. (2011). Öğretim ilke ve yöntemleri (Ed. G. Ocak), Öğrenme - ögretme süreci, (ss. 159-196), Ankara: Pegem Akademi.

Özkök, E. (2010). Gagne’nin öğretim modeliyle hazırlanan öğretim yazılımının ilköğretim 8. sinıf ögrencilerinin matematik dersi kareköklü sayılar konusundaki akademik başarısına ve ögrrenci tutumlarına etkisi, Yüksek lisans tezi, Gazi Üniversitesi.

Senemoğlu, N. (2010). Gelişim, ögrenme ve ögretim: Kuramdan uygulamaya, Ankara: Gazi Kitapevi.

Sönmez, V. (2007). Program geliştirmede ögrretmen el kitabı, Ankara: Anı Yayınc1lık.

Sünbül, A. M., Gündüz, Ş. \& Yılmaz, Y. (2002). Gagne'nin öğretim etkinlikleri modeline göre hazırlanmış bilgisayar destekli öğretim uygulamasının öğrencilerin erişi düzeylerine etkisi, Selçuk Üniversitesi Eğitim Fakültesi Dergisi, (14), 379-404.

Tanyeri, T. (2004). Fen bilgisi öğretmenlerinin web tabanl öğretime ilişkin görüşlerinin belirlenmesi: Illkögrretim 8. sinıffen bilgisi dersi madde ve enerji ünitesinin Gagne'nin ögretim modeline göre web tabanlı ögretimi, Yüksek lisans tezi, Anadolu Üniversitesi.

Taşdemir, M. (2003). Eğitimde planlama ve değerlendirme, Ankara: Ocak Yayınevi.

Taşpınar, M. \& Atıcı, B. (2002). Öğretim model, strateji, yöntem ve becerileri/teknikleri: kavramsal boyut, Eğitim Araştırmaları, 2(8), 207-215.

Taşpınar, M. (2012). Kuramdan uygulamaya ögretim ilke ve yöntemleri, Ankara: Elhan Kitap.

TDK (2019). Güncel Türkçe sözlük (öğretim), http://www.tdk.gov.tr/index.php?option= com_gts\&arama=gts\&guid=TDK.GTS.5d95bd1f679845.54191552, Erişim Tarihi: 03.06.2019.

Varış, F. (1996). Eğitimde program geliştirme: Teori ve teknikler, Ankara: Aklım Kitapç11ık.

Yeşilyaprak, B. \& Uçar, E. (2012). Eğitim psikolojisi (Ed: B. Yeşilyaprak), Öğrenmeden ögretime (ss. 337-398), Ankara: Pegem Akademi.

Yeşilyurt, E. (2019a). İşbirliğine dayalı öğrenme yöntemi: Tüm teknikleri kapsayıcı bir derleme çalışması, Turkish Studies Educational Sciences, 14(4), 1941-1970.

Yeşilyurt, E. (2019b). Değerler eğitimine uygunluğu açısından öğretim yöntem ve tekniklerinin incelenmesi: Bir derleme çalışması, Ekev Akademi Dergisi, 23(77), 121-146.

Yeşilyurt, E. (2013). Öğretmenlerin öğretim yöntemlerini kullanma amaçları ve karşılaştıkları sorunlar, Atatürk Üniversitesi Sosyal Bilimler Enstitüsü Dergisi, 17(1), 163-188.

Yeşilyurt, E. (2012). Öğretmen adaylarının bilişsel alanla ilgili sınama durumu soruları yazma yeterliklerinin değerlendirilmesi, Kastamonu Eğitim Fakültesi Dergisi, 20(2), 519-530.

Yıldırım, B. (2015). Eğitsel oyun ve dönüt-düzeltmenin öğrenme düzeyi ve kalıcllı̆g etkisi, Yüksek lisans tezi, Necmettin Erbakan Üniversitesi. 